\title{
A Word from the Editors
}

Last year, Theological Librarianship (TL) issued a call for proposals for a forum devoted to diversity, equity, and inclusion (DEI), hoping to further conversations we felt to be important within our profession and our larger society. We had aspired to raise up voices to speak not simply about these issues, but to them respectfully, productively, and innovatively. The events of 2020 redefined the standards for such a contribution. Our attempts to assemble the intended forum for publication in this issue within a rapidly transforming context made us keenly aware of the limits of our expertise, the limits of our professional networks, and, indeed, the limits of our original vision.

For this reason, the editorial board decided not to proceed with the forum. This decision represents no weakening of our commitment to the ideals of DEI but, rather, reflects the seriousness with which we take that commitment. As our nation, our profession, our organization, and our journal strive to address and remedy historical inequities and injustices, we at $T L$ find ourselves called to explore other, more systemic ways to realize our commitment. We still want to foster desperately needed conversations that have already grown far beyond our original call and that demand more sustained engagement than a single-issue forum can provide. We cannot do that, however, without your continued engagement as a community of readers, a community of reflective practitioners, and, ultimately, a community of writers. So we invite you once again, not in an isolated call with an arbitrary deadline, but in a perpetual and ongoing appeal born out of Theological Librarianship's underlying mission, to join us in this endeavor.

In the meantime, we wish to recommend some vital contributions to the discourse around diversity, equity, and inclusion that have stood out to us elsewhere in our professional community during the past year (see next page). We also remain proud of the contributions we are able to make to other conversations in this issue. Our opening article, from Megan E. Welsh, Ian Burke, and James Estes, sheds valuable light on the response of theological libraries to the COVID-19 pandemic, updating prior studies and providing greater clarity about the challenges faced by our institutions within the wider profession of librarianship. In our second article, meanwhile, Paul Hartog explores the career of the third-century scholar Pamphilus of Caesarea Maritima, illuminating the distinctive contributions of theological librarianship to librarianship more broadly conceived and emboldening us to believe that we may yet have unique roles to play in the transformations of our own age.

To that end, a particularly strong raft of reviews closes the issue, highlighting titles that can help us to expand our vision and reframe the terms of our debates. Zachariah Motts's treatment of the new Oxford Handbook of Latin American Christianity and David Carr's analysis of the Global Wesleyan Encyclopedia of Biblical Theology call our attention to resources that can broaden and diversify our understanding of theology's global practice, while Clifford B. Anderson's review of Andrew Ventimiglia's Copyrighting God and Micah Saxton's exploration of the new edited collection Putting God on the Map: Theology and Conceptual Mapping point toward new engagements between theology and the fields of intellectual property law and cognitive linguistics, respectively. While some theologians may see these disciplines as unlikely partners, their rich potential for dialogue around issues of meaning, identity, authenticity, and ownership will be clear to librarians in theology and religion and may yet spark, in one of our readers or another, the kind of insights and reflections that will allow us, in future issues, to return to DEI conversations in a way that rises to the challenge not of the moment-for it belongs to far more than a moment-but of the times. 
As always, we remain grateful for your time, which has only grown more precious and which, as we know, moves so quickly.

Sincerely,

the Editors

\section{SUGGESTED READING}

Atla's DEI Committee maintains an active LibGuide with curated lists of readings in multiple DEI areas, which we recommend as a starting point. In addition, there are several titles that we have found worthwhile in our own reflections on these issues or are looking forward to as new releases:

Carter, Kameron, J. 2008. Race: A Theological Account. Oxford: Oxford University Press.

Chesley, Camille and Tarida Anantachai. 2018. "The Burden of Care: Cultural Taxation of Women of Color Librarians on the Tenure-Track." In Pushing the Margins: Women of Color and Intersectionality in LIS, edited by R. Chou and A. Pho, 301-27. Sacramento, CA: Library Juice Press.

Coleman, Anita. 2020. "Using the Anti-racism Digital Library and Thesaurus to Understand Information Access, Authority, Value and Privilege.” Theological Librarianship 13, no. 1: 1-12.

—. 2016. “Theology, Race and Libraries.” ATLA Summary of Proceedings 70: 65-74.

Day, Keri. 2021. Notes of a Native Daughter: Testifying in Theological Education. Eerdmans.

Delgado, Richard and Jean Stefancic. Critical Race Theory: An Introduction. New York: New York University Press, 2012.

Leung, Sofia Y. and Jorge R. López-McKnight. 2021. Knowledge Justice: Disrupting Library and Information Studies through Critical Race Theory. MIT Press.

Roh, Charlotte and Vanessa Gabler. 2020. "Systemic Barriers and Allyship in Library Publishing: A Case Study Reminder That No One Is Safe from Racism.” CRL News 81, no. 3. 